\title{
En stærk bryder og en hurtig cykelrytter \\ - sportens gennembrud i Vejle
}

\section{Af Poul Porskar Poulsen}

»Naar Vejle har Ord for at vare en Sportsby, da er det ogsaa med Rette, thi i faa Byer forer naesten enhver Gren af Sporten en saa virkelig levedygtig Tilvarelse som $i$ Vejle, om end kun enkelte have havet sig højt over Sportsniveauet med Hensyn til indvundne Resultat af Saesonens Arbejde.

Naar der ses hen paa hvilket umaadeligt Fremskridt Sportens Udvikling er undergaaet $i$ den sidste halve Snes Aar med nye Metoder og til Dels nye Sportsgrene, vil man forstaa, at den har faaet et urokkeligt Tag i Folk, og noesten er at betragte som en Livsbetingelse for Tilvarelsen, og Sporten har, naar den drives korrekt, $i$ sin Helhed en absolut gavnlig Indflydelse paa dens Udøvere, det vare sig saavel Haandvarkere som Folk af Handels- og Kontorstanden. Og netop dette giver os Grunden til, at Sporten nu til Dags har naaet en Højde, som man i tidligere Tider vel narmest vilde regne hen under Artisterne«.

Citatet fra Vejle Amts Avis den 19. december 1899 , forfattet af signaturen $»$ Spurt«, fastslog som en kendsgerning, at Vejle var en rigtig sportsby. Mange vejlensere dyrkede en eller anden form for sport, men det var dog endnu så som så med de helt store sportslige præstationer.

Det er ikke usædvanligt at finde citater som dette i provinsens dagblade. Mange andre byer kaldte sig for rigtige sportsbyer, måske endda landets fremmeste; ${ }^{1}$ der var blot tale om nogle få års forskydning mellem provinsbyernes sportslige udvikling $\mathrm{i}$ den periode, som er blevet kaldt sportens gennembrudsperiode. Det vil sige, at sport og idræt hører op med at være leg og adspredelse; der sigtes efter høj organisering og gode resultater, der bygges idrætsanlæg, og de bedste træningsmetoder finder anvendelse. ${ }^{2}$

Provinsbyen Vejle havde også sin plads i denne udvikling, som vil blive berørt ved hjælp af sportsåret 1899. Gennem en af de lokale aviser, Vejle Amts Avis, er det muligt at tegne et omrids af sportslivet i Vejle, og $i$ det følgende vil vi se på avisens omtale af lokale sportsbegivenheder i dette år.

\section{»... naaede højest $i$ \\ Sidespring «}

Den citerede artiklen i Vejle Amts Avis den 19. december 1899 handlede især om vinteridrætten i Vejle. Det vil sige den idræt, der foregik inden døre, gymnastikken og atletsporten. Gymnastikken kom naturligvis først, idet de gymnastiske $\varnothing$ velser var en del af skyttekredsens program fra 1860 'erne for at udvikle gode soldater til forsvar for fædrelandet, men som en selvstændig idrætsgren døde den lidt bort, indtil der blev dannet en egentlig gymnastik- 


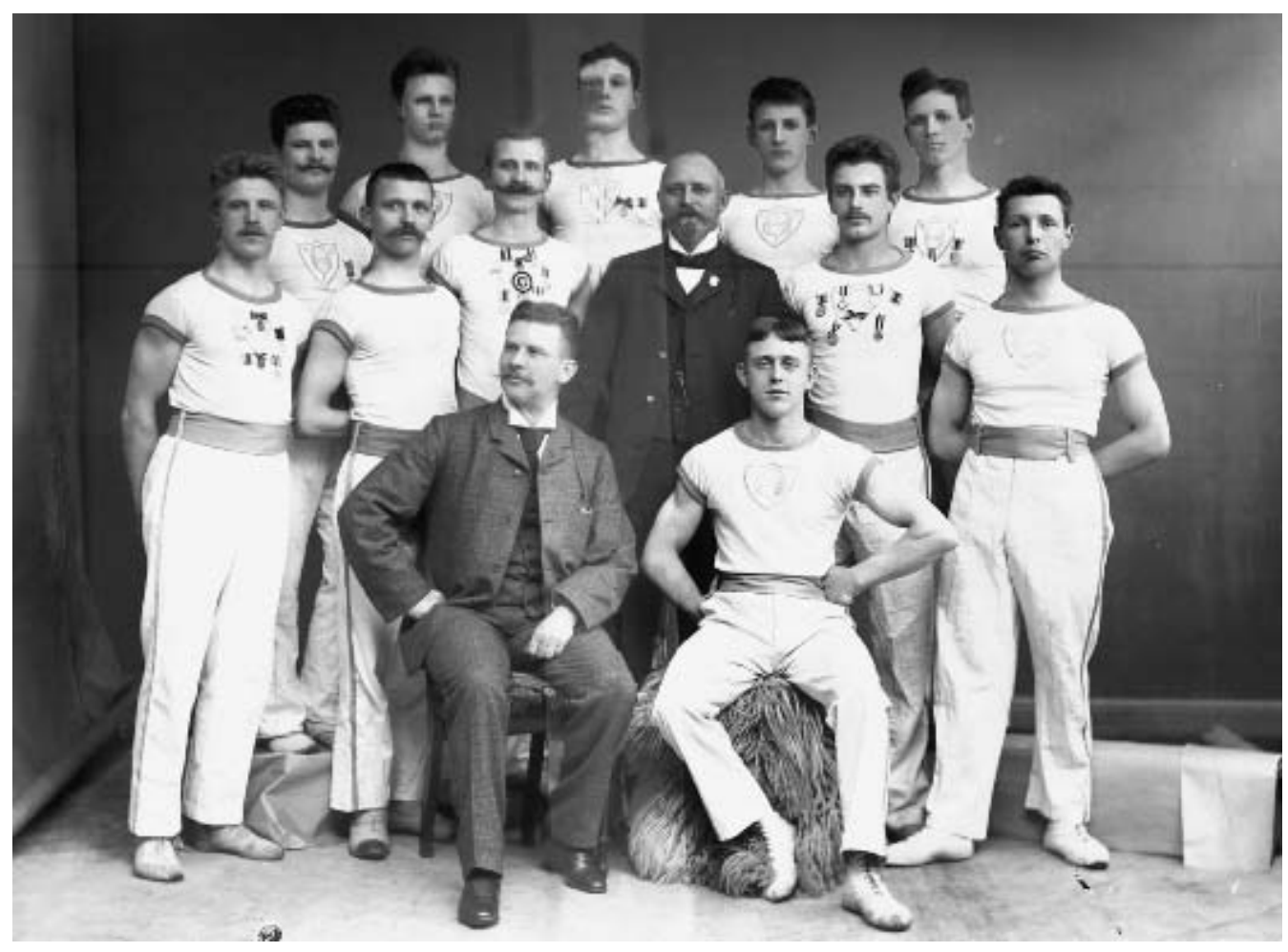

Gymnaster og ledere fra Vejle Gymnastikforening hos fotografen. (Foto: H.P. Jensen. Vejle Byhistoriske Arkiv \& Stadsarkiv).

forening. »Spurt « slog fast, at gymnastikken var den sport, der havde den største alsidige indflydelse på udøverne, og i 1899 havde gymnasterne også nået et vist niveau.

Gymnastiklederen, løjtnant C.F.A. Ishøy, havde allerede tidligere på året i et læserbrev formuleret sig om det vigtige $i$ at dyrke gymnastik. For selvom man havde nok så fysisk et arbejde, så var det ofte af en ensidig karakter, og her kunne gymnastikken hjælpe til at styrke alle muskler. Man skulle uddanne legemet, og i gymnastikken fandtes den bedste vej. ${ }^{3}$

I »Spurt«s omtale af gymnastikken fremførtes både den fysiske udfoldelse, som i sig selv værende godt for mennesket, og sportsaspektet: at blive så god som muligt og evt. vinde konkurrencer. Og gymnasterne holdt sig sandelig heller ikke tilbage med hensyn til at konkurrere med hinanden.

I december 1899 udkæmpede Vejle Gymnastikforening en gymnastikkonkurrence mod Horsens. Begge hold lavede gode præstationer: »Horsensianerne naaede $h \phi$ jest $i$ Sidespring og Vejlenserne højest $i$ Højdespring og Bagspring «, men især spring over hest, hvor vejlenserne var specielt gode i nedspringet, afgjorde kampen til Vejles fordel. Bedst hos Vejle Gymnastikforening var kommis P. Jensen, hvis »enestaaende Sikkerhed og Ro under de flot udførte Prastationer gjorde ham hele 
Aftenen til Publikums Yndling og indbragte ham bragende Bifald«.

Vejle Amts Avis kunne efterfølgende berette, at konkurrencen også havde været rosende omtalt i Aarhuus Stiftstidende, hvor man måtte medgive, at Aarhus Gymnastikforening ikke ville kunne klare sig over for Horsens og Vejle. Det var man naturligvis glade for at høre i de mindre byer syd for Århus! ${ }^{4}$

Vejle Atletklub var en anden af de foreninger, der tilbød fysisk udfoldelse inden døre i vinterhalvåret. Endnu et læserbrev beskrev denne idræt. Formanden for Vejle Atletklub, slagter Carl Laursen, opfordrede de unge mennesker til at komme til træning i den kommende vinter i ridehuset på Blegbanken, og han definerede, hvem han henvendte sig til: »[Atletsporten] som jo er en Gren af Gymnastikken, og vasentlig bor dyrkes af svare Folk eller $i$ det hele Taget af unge Mennesker, som mener at vare uskikkede til Dyrkning af Gymnastik«. Laursen nævnte ikke noget om konkurrence, ligesom det heller ikke var tilfældet med gymnastikfortaleren Ishøy. Deres interesse i sporten lå på et andet sted, nemlig hvordan man udviklede »sunde kroppe $\ll{ }^{5}$

I $\gg$ Spurt «s artikel blev der igen lagt vægt på konkurrence i forbindelse med atletsporten. Også her havde der været udkæmpet kappestrid med atletklubber fra nogle af de omkringliggende byer, Fredericia, Kolding og Varde, og her var mesterskabet i brydning gået til Vejle. I avisen blev der i løbet af 1899 nævnt mindst ti stævner og præsentationer, hvor Vejle Atletklub havde været deltager.

Som afslutning på sin gennemgang af vintersporten i Vejle nævnte »Spurt« desuden, at der fandtes en skøjteløberfor-

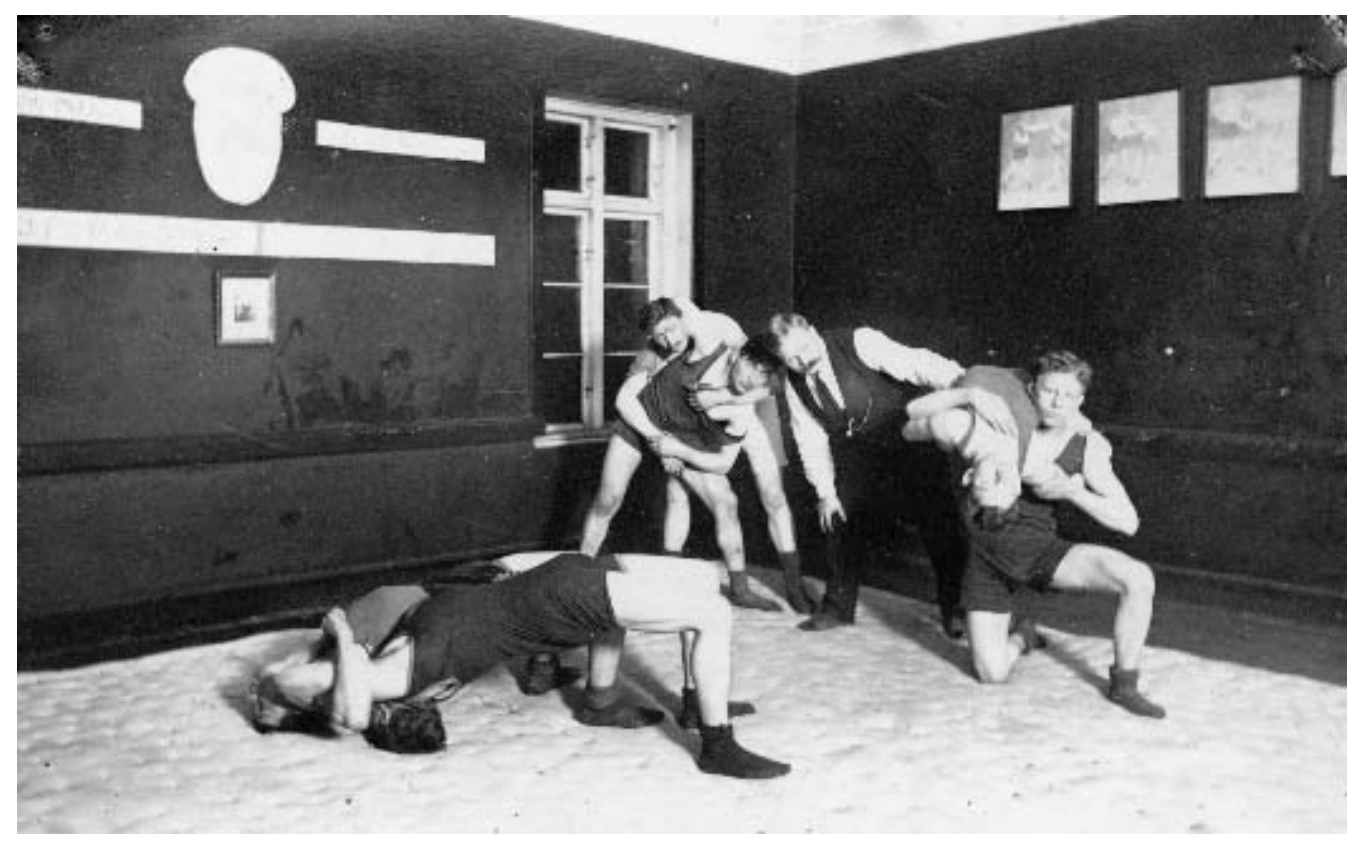

Traningsaften $i$ Vejle Atletklub under Hjalmar Christensens instruktion ca. 1910. (Vejle Byhistoriske Arkiv \& Stadsarkiv). 
ening, som dog ikke havde ydet noget egentligt sportsligt endnu. Men hvis ellers isforholdene var gode, så havde man planer om at $\varnothing v e$ både væddel $\varnothing b$ og kunstl $\varnothing b$, forhåbentlig på en fast bane. Skøjteløberforeningen har ikke efterladt sig arkivalier, men i avisen 1899 kan man se, at der dette år ikke var særligt godt skøjtevejr. Skøjtebanen var anlagt i engene bag banegården, og for at man kunne få is at løbe på, måtte det jo være frostvejr. Da det ikke var tilfældet i 1899, havde foreningen efterhånden oparbejdet en ganske pæn kassebeholdning. Ved generalforsamlingen i december 1899 lød beløbet på 972 kr. og 22 øre. Forskellige forslag fra forsamlingen om at bruge pengene, bl.a. til bal for medlemmerne, blev på det bestemteste afvist af bestyrelsen. Pengene skulle bruges til is! Formanden for foreningen var i $\varnothing$ vrigt den tidligere nævnte løjtnant Ishøy. ${ }^{6}$

Skiløb var der næsten ikke noget af i Vejle, og det stod heller ikke så godt til med fægtning, der »ncermest have en trist Karakter«. »Spurt« nåede også lige at komme ind på fodbold, der endnu ikke trivedes i Vejle. Selvom der havde været gjort forsøg i den forløbne sæson, var fodbolden nu død, »vel naermest fordi kyndig Ledelse af denne Sport savnedes«.

\section{»... at spille ordentlig Fodboldt«}

Det har længe været et mindre mysterium, hvornår fodbold egentlig kom til Vejle, men noget kunne tyde på, at med Vejle Fodsportsforenings bestræbelser i 1899 blev sporten for første gang organiseret i byen. I januar 1899 rapporteredes det i avisen, at fodsportsforeningen nu var begyndt sine $\varnothing v e l s e r$, og at man planlagde at afholde turneringer med andre klubber.
Det første fors $\varnothing \mathrm{g}$ med en kamp mod et udefrakommende hold fandt sted den 19. marts 1899. Kampen, der blev betegnet som ganske respektabel, skønt der var alt for mange frispark, blev spillet mod Fredericia Fodsportsforening »Frem $«$ og resulterede $\mathrm{i}$ et hæderligt nederlag for vejlenserne på 0-1. Holdet fra Fredericia havde åbenbart spillet længere tid end Vejle Fodsportsforenings hold, for de var noget bedre sammenspillede, men i anden halvleg optrådte fredericianerne dog noget »mattere«, og det ene mål, der blev scoret $\mathrm{i}$ første halvleg, forblev kampens eneste. Avisen mente, at foreningerne gennem $\varnothing$ velse ville komme til »at spille ordentlig Fodboldt «. Efter kampen samledes alle spillerne til fællesspisning på Turisthotellet. ${ }^{7}$

Der blev aftalt en revanchematch om efteråret, men den blev udsat et par gange og formodentlig aldrig spillet, for det stod ikke for godt til med Vejle Fodsportsforening, der blev opløst i november måned. Den var gal med økonomien, så den 12. november 1899 afsluttede foreningen sin korte eksistens med et bal. ${ }^{8}$

Den klub, der senere skulle blive byens førende fodboldklub, Vejle Boldklub, havde endnu ikke taget dette boldspil op. Det var kricket, det drejede sig om i stedet. Det vil sige, lige i 1899 var der åbenbart lidt stilstand. I hvert fald beklagede $»$ En Ynder af Kricketsporten «, at der ikke var noget spil i gang. Der var ikke noget kricket at se på, og skribenten undrede sig over hvorfor. Måske et nederlag til Horsens tidligere på året? Men sådan skulle man ikke opføre sig; det var blot om at komme i gang igen. Og måske var det også bare sommerferiestemning i juli, for $i$ august var der kamp mod Fredericia. De sydøstlige naboer fik klø, »vel naermest fordi disse ikke vare fortrolige med Vejlensernes fortrinlige Overhaandskast «. Netop overhåndskast blev VB's kendemær- 


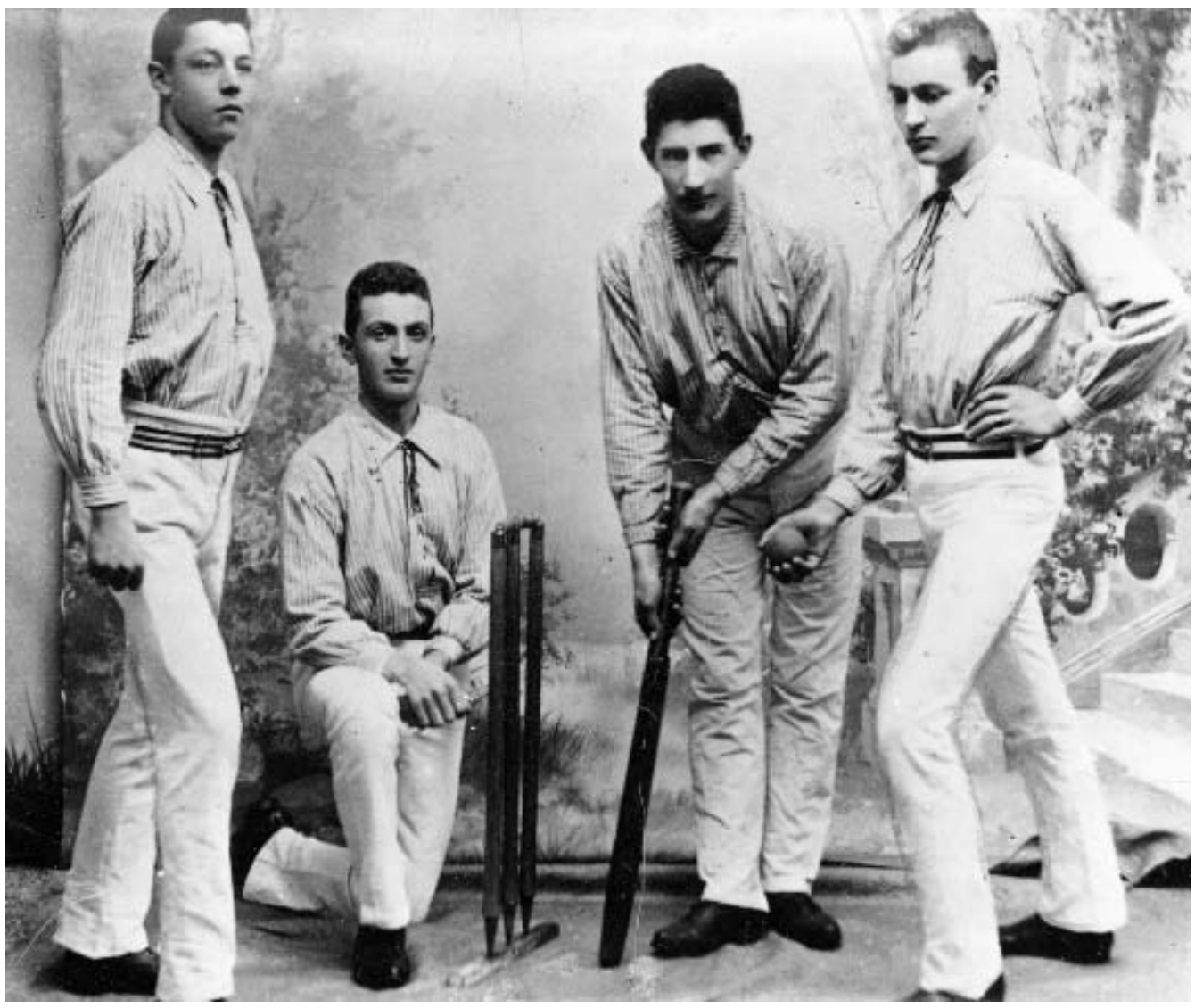

Kricketspillere i Vejle Boldklub ca. 1900 (Vejle Byhistoriske Arkiv \& Stadsarkiv).

ke på dette tidspunkt. Den hidtil ukendte detalje i kastningens ædle kunst var indført i klubben af englænderen Sam Sykes, og med det våben slog VB de fleste modstandere i slutningen af 1890 'erne.

\section{Med båd og på cykel}

Sejlklubben Neptun var også aktiv i 1899. Der blev arrangeret flere kapsejladser på fjorden. F.eks. den 4. juni, hvor Marineministeriet havde udlånt kanonbåden »Falster « som dommerbåd, og her kunne gæster og officials hygge sig, mens sejladserne foregik:
»Chefen, Kaptajn Foss og Skibets фvrige Officerer udviste den største Imødekommenhed og Elskvardighed saavel over for Bestyrelsen som overfor de Damer og Herrer, der efter sidstncevntes Indbydelse overvarede Kapsejladsen om Bord $i$ »Falster«. Heller ikke maa vi forglemme at komplimentere det lille, flinke Sangkor blandt Mandskabet for en Rakke Sangnumre, de saa smukt gav til bedste«.

Det har været en hyggelig søndag på fjorden, ikke mindst når sangkoret lod stemmerne gjalde mellem Tirsbæk og Munkebjerg! 
I selve sejladserne var der tilmeldt 26 både, men »Antilope « kom dog ikke til start. Fritz Hansens »Sofie« kuldsejlede under Bredballe Strand, og mandskabet måtte reddes af tililende fartøjer. På både $»$ Elf $«$ og $»$ Trold « røg en mand over bord, men uden at komme til skade. ${ }^{9}$

Der var også en cykelklub i Vejle. Vejle Cykleklub afholdt løb på sportspladsen ved Horsensvej, ligesom landevejsløb hørte til programmet. Klubben havde desuden i Rasmus Jørgensen en sand mester i udholdenhedsløb. Ham skal vi vende tilbage til.

Den 14. maj afholdtes et lokal cykelløb over seks mil - fra Mølholm til Snoghøj og tilbage igen. Cykelreparatør Andersen vandt i tiden en time, 32 minutter og ti sekunder. Førstepræmien var et vækkeur.

Den 11. juni var der igen landevejsløb, og her var ryttere fra Horsens, Tørring, Fredericia og Kolding indbudt. Der kom nu ikke ret mange af de indbudte, for samme dag var der baneløb i Kolding. Distancen var ca. ti mil på ruten Vejle-SnoghøjKolding-Fredericia. Wold fra Vejle vandt fem sekunder foran Rasmus Jørgensen fra Vejle, og præmierne var hhv. et barometer og to kompotskeer. ${ }^{10}$

I juli var der baneløb på sportspladsen, og avisen var i sin foromtale tilfreds med, at pladsen denne gang var pyntet, at der kunne reserveres plads på inderkredsen, og at »efter Forlydende [vil] Fredericia Brigademusik musicere under Løbene«. De forskellige løb gik fint, skønt enkelte ryttere kom lettere til skade, men de 800 tilskuere fik »flere smukke Enkeltheder «. De dominerende ryttere var Wold, Vejle, og Holdersen fra Kolding. ${ }^{11}$

Endelig nævner avisen i 1899 yderligere tre klubber: Vejle Fodsportsforening »Frem «, der blev stiftet i maj måned, og Vejle Fodsportsforening »Skjold «, stiftet i juli med 25 medlemmer. Ingen af de to for- eninger høres der yderligere om senere. Den tredje var Vejle Fodsportsforenings atletikafdeling, der afholdt idrætsfest den 2. juli. En fest der samlede 1.200 tilskuere på sportspladsen. Foreningen ophørte som tidligere nævnt i november samme år pga. pekuniære vanskeligheder.

\section{Sportsklubberne $i$ Vejle}

I det foregående er nævnt nogle af de klubber, der i slutningen af det 19. århundrede prægede Vejle Amts Avis' spalter. Der havde selvfølgelig været flere, og endnu flere skulle komme til. For interessen for sporten tog til i begyndelsen af det 20. århundrede. Det er typisk, at antallet af sportsklubber og dermed formodentlig også antallet af ud$\emptyset$ vere eksploderede på dette tidspunkt. Sporten er blevet benævnt bykulturens og industrialiseringens kropslige udtryk med ekspansion, rationalisering og specialisering som væsentlige begreber, og det var netop på dette tidspunkt, at byvækst og industri i skøn forening tordnede frem. Vejle oplevede sit egentlige industrielle gennembrud i perioden ca. 1890 til 1. Verdenskrig, hvor en lang række fabrikker blev anlagt, og byen voksede langt ud over de hidtidige grænser. Og det var også i den periode, sportsklubberne voksede frem. Tendensen var helt generel: Perioden i slutningen af det 19. århundrede og lidt ind i det næste århundrede var gennembruddet for sporten i Danmark som sådan. ${ }^{12}$

Sporten voksede altså frem omkring dette tidspunkt med nogle års forskydning mellem de enkelte byer, som regel i sammenhæng med industrialiseringens gennembrud. Vi har allerede berørt nogle af Vejles sportsklubber gennem deres aktiviteter i 1899, men flere nye klubber så dagens lys, og mange af dem findes stadig. Nogle af de vigtigste skal omtales her. 


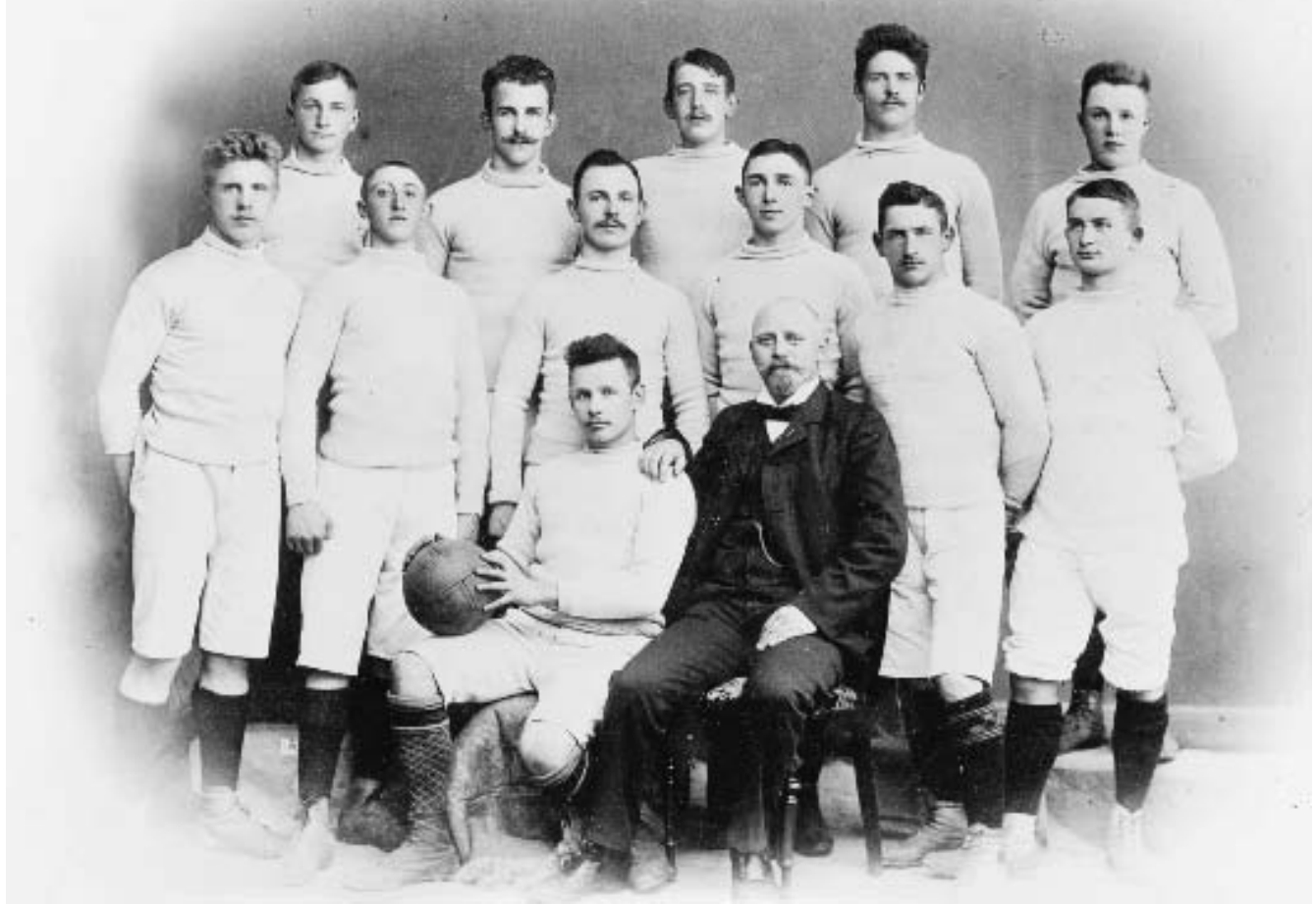

Vejle Boldklubs fodboldhold, formodentlig fra perioden 1907-1912, hvor VB spillede $i$ hvide trøjer. (Vejle Byhistoriske Arkiv \& Stadsarkiv).

Vejle Boldklub blev dannet den 3. maj 1891. Gennem det 20. århundrede er klubben kendt først og fremmest for fodbold, men der har også været håndbold, ja, sågar svømning på programmet. Fra begyndelsen var det dog kricket, det drejede sig om. Den første match blev spillet den 6. september i etableringsåret mod Horsens. $\varnothing v e l s e s p l a d s e n$ var den gamle markedsplads, hvor nu Vor Frelsers Kirke ligger, og tidspunktet var tidligt om morgenen, tirsdag og torsdag 5.30-6.30, og om søndagen fra kl. 9 til 12. Senere kunne kricket- $\varnothing$ velserne finde sted på sportspladsen ved Horsensvej, og spillerne fra VB blev ganske gode til kricketspillet, angiveligt som følge af overhåndskastet, som indførtes direkte fra England med Sam Sykes, der arbejdede på bomuldsspinderiet. Det jyske mesterskab i kricket blev vundet i 1896, 1897 og 1900. Der blev fortsat dyrket kricket i klubben i nogle år derefter, men fodbold blev fra begyndelsen af det 20. århundrede den vigtigste sportsgren, ikke mindst efter at fodboldklubben »Fremad « en bloc havde meldt sig ind i klubben i 1902. Igen var den første noterede kamp imod Horsens og det gik godt. Sejren lød på 4-3. Op imod 1. Verdenskrig vandt klubben flere jyske mesterskaber. Som et kuriosum bør det nævnes, at historikeren Torben Jacobsen i en artikel i Idrcetshistorisk Årbog 1986 kunne afsløre, at det ved en generalforsamlingsbeslutning i 1906 blev vedtaget, at 


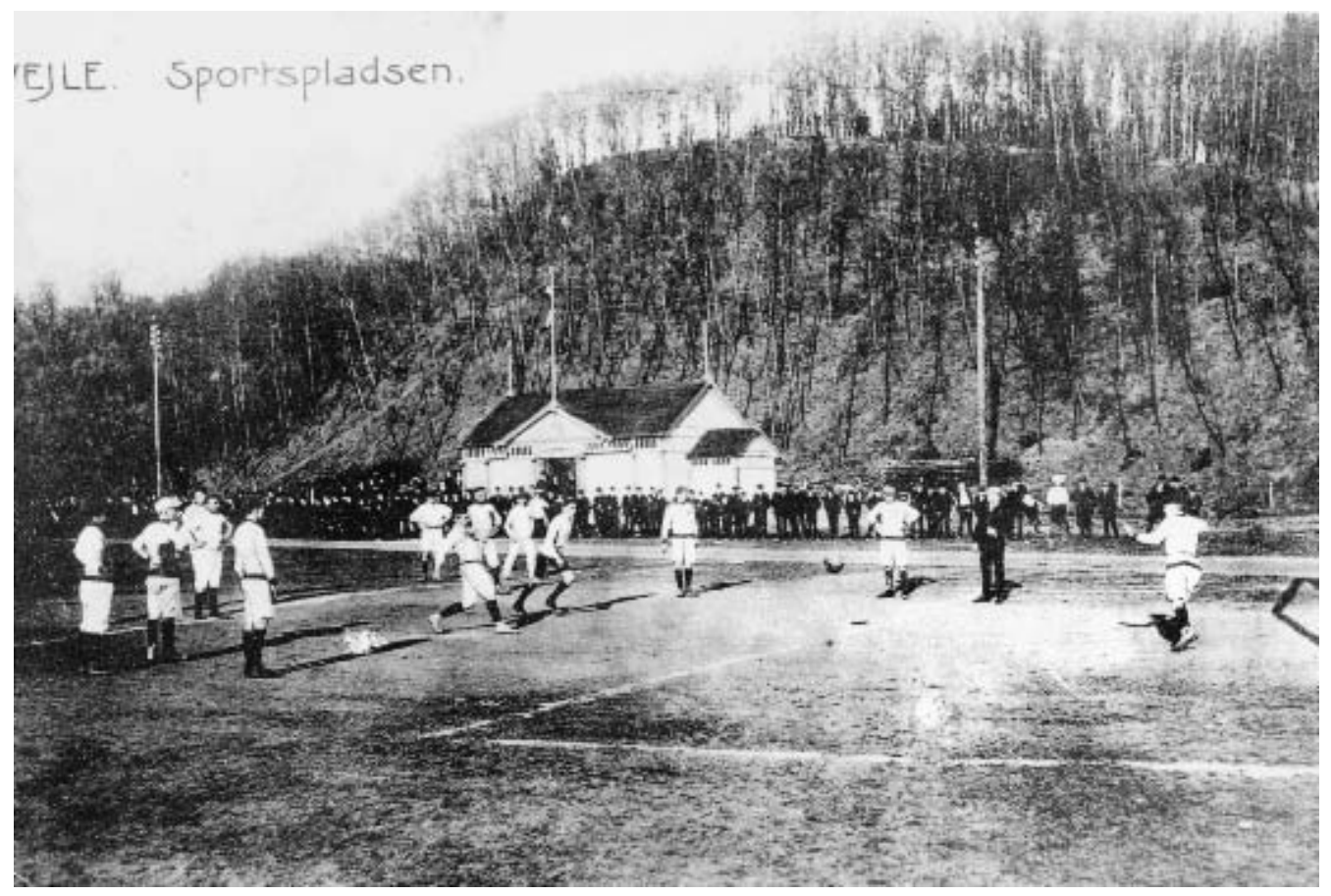

Fodboldkamp i gang på den gamle sportsplads ved Horsensvej. I baggrunden VB's klubhus. (Vejle Byhistoriske Arkiv \& Stadsarkiv).

kvinder kunne optages som medlemmer og hvis der var tilslutning nok, kunne man også danne et damefodboldhold. Der er dog ingen vidnesbyrd om, at dette nogensinde blev ført ud i livet, men muligheden eksisterede altså. ${ }^{13}$

Sejlklubben Neptun er byens ældste kendte forening, hvis man ser bort fra skyttekredsen. Den 13. august 1881 indbød nogle af byens førende mænd med tilknytning til havnen såsom købmænd, skibsbyggere m.v. til det stiftende møde. Neptun havde fra begyndelsen 30 medlemmer, men medlemsskaren voksede hastigt. Den første kapsejlads på fjorden blev afholdt den 23. juni 1882 med deltagelse af 42 fartøjer fra flere forskellige byer. Formålsparagraffen talte ellers ikke om egentlig kapsejlads:
»Foreningens Formaal er at fremme Lystsejlads paa Vejle Fjord ved at danne et Bindeled mellem de Mand der føler Lyst og Trang til at give sig af med denne Idrat, og at udvikle Bygningen af Baade ved at fremkalde de bedste Former, samt at vakke Sansen for Lystsejlads paa Vejle Fjord«.

Men med til lysten til at sejle hørte altså også, som vi har hørt i 1899, lysten til at konkurrere, så de årlige kapsejladser internt og med deltagelse fra andre byer blev vigtige milepæle i foreningens liv. ${ }^{14}$

Vejle Gymnastikforening blev dannet i 1895 som en sammenslutning mellem de to daværende - og kriseramte - gymnastikforeninger. Vejle Gymnastiske Forening fra 1888 henvendte sig primært til handels- 
og kontorstanden i modsætning til den lidt ældre gymnastikforening Frejr, der koncentrerede sig om håndværkerne. Vejle Gymnastiske Forening afholdt sine $\varnothing v e a f-$ tener i byens eneste gymnastiksal i Borgerskolen på Kirketorvet, og allerede den 24. februar 1889 blev den første opvisning afholdt. Men som nævnt kom det ret hurtigt til at knibe med gymnastikinteressen, i hvert fald til to foreninger, og den logiske konsekvens var naturligvis, at man slog kludene sammen i den nye foreningsdannelse, Vejle Gymnastik-Forening. I begyndelsen var der kun tale om mandsgymnastik, men fra 1907-1908 kom også kvindegymnastikken med. ${ }^{15}$

Vejle Atletklub koncentrerede sig om brydning, vægtløftning og boksning, og træningen foregik på den bare jord i ridehuset på Blegbanken. Stiftelsen af klubben skete den 21. november 1897, og året efter havde klubben den første opvisning i Vingsted Krohave. Det første store navn i klubben var Carl Nielsen, der ved en opvisning i 1901 bar en kuglestang på 150 pund belastet af fem mænd, og senere ved samme stævne stod han »i bro« med 1.000 pund på brystet. Gustav Heede var en endnu større sportsmand, der vandt nationale mesterskaber i brydning. Ham vender vi også tilbage til. ${ }^{16}$

Vejle Lawn Tennis Klub blev dannet på Hotel Royal den 3. april 1900. Ved etableringen blev klubben benævnt Vejle $\mathrm{Ny}$ Lawn Tennis Klub, og navnet kunne tyde på, at der tidligere havde været en tennisklub, men noget vidnesbyrd findes ikke. De første år hører man ikke meget om det sportslige fremskridt. Indføringerne i forhandlingsprotokollen fortæller mere om de sociale sammenkomster end selve spillet. Klubben havde to baner i sandbakkerne ved sygehuset, men åbenbart ikke i den rigtige størrelse, for i 1909 blev det vedta- get at anlægge en ny tennisbane med rigtige mål og renovere de to gamle. Klubben kom efterhånden med i Jydsk Lawn Tennis Unions turnering, men nogen særlig entusiasme synes der ikke at have været over spillet, for i 1914 beklagede formanden sig over, at medlemmerne kun viste iver i spillet ved forårssæsonens begyndelse, derefter gik det ned ad bakke. Heller ikke i årene derefter udviste klubbens spillere nogen særlig sportslig fremgang. ${ }^{17}$

Vejle Roklub blev oprettet den 13. maj 1901. Tidligere havde der været rosport på fjorden under private former, men nu blev ro-entusiasmen organiseret. Som en væsentlig grund til oprettelsen af foreningen blev angivet, at den passede så godt sammen med vintergymnastikken. I begge sportsgrene fik man nemlig rørt rigtig mange muskelgrupper. Klubben kom hurtigt $\mathrm{i}$ besiddelse af to både, som medlemmerne så måtte deles om, og fra begyndelsen fik man også opført et klubhus. Rodragten bestod af $\gg$ Blaa ensfarvet Sportshue (engelsk Facon), hvid ulden Trøje, mørkt-marineblaa Knabenklader og lange do. do. Strømper«. Det gav sig selv, at strømper og benklæder skulle være så lange, at man ikke kunne få et glimt af et bart mandeben. I mange år var rosporten i Vejle kun for mænd, men fra 1919 kom kvinderne også med, for dog at blive udelukket $\mathrm{i}$ 1925 med begrundelse i, at der manglede omklædningsmuligheder, og at der var for vanskelige sejlforhold i havnen med den store udvidelse, der foregik på dette tidspunkt. I 1932 måtte damerne derfor danne deres egen klub: Vejle Dame Roklub. ${ }^{18}$

Vejle Idrcetsforening var ikke den første i Vejle til at $\varnothing v e$ fri idræt eller atletik. Vejle Fodsportsforening, som tidligere er nævnt især som fodboldklub i sæsonen 1899, var egentlig en atletikforening, der bl.a. stod som arrangør af de første jyske mesterska- 
ber på markedspladsen i 1897. Men den forening holdt kun til 1899. I en række år var der ikke ordentlig organiseret atletikudøvelse i Vejle. Men det kom der i 1907. Her indkaldte tre unge interesserede vejlensere til et møde 7. maj, og Vejle Idrætsforening blev stiftet. Omkring fodboldbanen på sportspladsen var der en jordbane, som tidligere havde været brugt af cykelklubben, og den kunne anvendes som løbebane. Herfra udgik også det første træningsløb allerede søndagen efter klubbens stiftelse. I foreningens formål kunne man se en dobbelt grund til at have en atletikforening: Den skulle udbrede gavnlig legemlig idræt, men skulle også sørge for lejlighedsvis at afholde konkurrencer. $\mathrm{Og}$ det sidste levede klubben op til allerede den 6. oktober 1907. Her blev nemlig arrangeret et stævne i samarbejde med Vejle Boldklub, og resultaterne blev nøje indført i protokollen. Stævnet havde udenbys deltagere, og VIF var så god en vært, at man lod de udenbys løbe med alle førstepladserne. P. Jørgensen fra Horsens var så alsidig, at han kunne vinde både 100-meterløb, højde- og længdespring, og også i spydkast, kuglest $\varnothing d$, hammerkast og en halv-mils $1 \varnothing b$ var vinderen fra Horsens. Idrætsstævnet bød også på en fodboldkamp, hvor AGF nedsablede VB med $7-1 .{ }^{19}$

\section{To profiler}

Sportslivet i Vejle omkring det forrige århundredskifte havde naturligvis også sine helte. De fleste af dem er gået i glemmebogen nu, men to vejlensiske sportsfolk, der blev landskendte, er det dog værd at nævne.

I omtalen af cykelsporten i 1899 blev Rasmus Jørgensen nævnt. Han var medlem af byens cykelklub, stiftet 1897, Vejle
Cykleklub. Han deltog i mange forskellige løb, men indlagde sig især hæder som en sej cykelrytter, der gik efter forskellige udholdenhedsrekorder.

I juni 1899 satte han sig således for at slå verdensrekorden i 24 timers landevejsløb uden pace. Den $\varnothing$ jeblikkelige verdensrekord lød på 68 danske mil, sat af en englænder. Rasmus Jørgensen ville indlede rekordfors $\varnothing$ get en lørdag aften kl. 7 fra Molgjer Kro og derefter køre ruten til Nørre Snede og tilbage igen så mange gange som muligt inden afslutningen 24 timer senere. Og det lykkedes faktisk Jørgensen at sætte ny verdensrekord ved med kun en times hvil at køre 71 en kvart mil på sin Citus-cykel. Rekordløbet blev overværet af adskillige cykelfans fra både Horsens og Vejle, og de hyldede efterfølgende Jørgensen med hurraråb.

I august samme år deltog Rasmus Jørgensen i et 28-mils cykelløb, KøbenhavnGedser og retur, og det vandt han suverænt. Kort tid efter kunne avisen meddele, at Rasmus Jørgensen nu ville begynde »som Professionals « på Odense-banen. Det har ikke været muligt at finde vidnesbyrd om en evt. karriere på banen i Fruens Bøge i Odense, men det ser ud til, at han bosatte sig i Odense-forstaden Dalum, måske for at være i nærheden af tidens cykelikon, Thorvald Ellegaard.

Den 22. september 1899 gjaldt det så rekorden i landevejsløb over $1.000 \mathrm{~km}$ uden pace. Strækningen, som Rasmus Jørgensen havde valgt til rekordfors $\emptyset$ get, var Bredal Kro-Ølsted, og igen kunne han lade sig hylde som ny verdensrekordholder. Han slog rekorden med godt seks timer og var endda to timer bedre end verdensrekorden med pace. »Rytteren har under hele Løbet kun hvilt under Maaltiderne og var endda efter Løbet fuldstondig frisk. Han kørte med $3^{1} / 2$ Mils Fart det meste af Tiden, og 


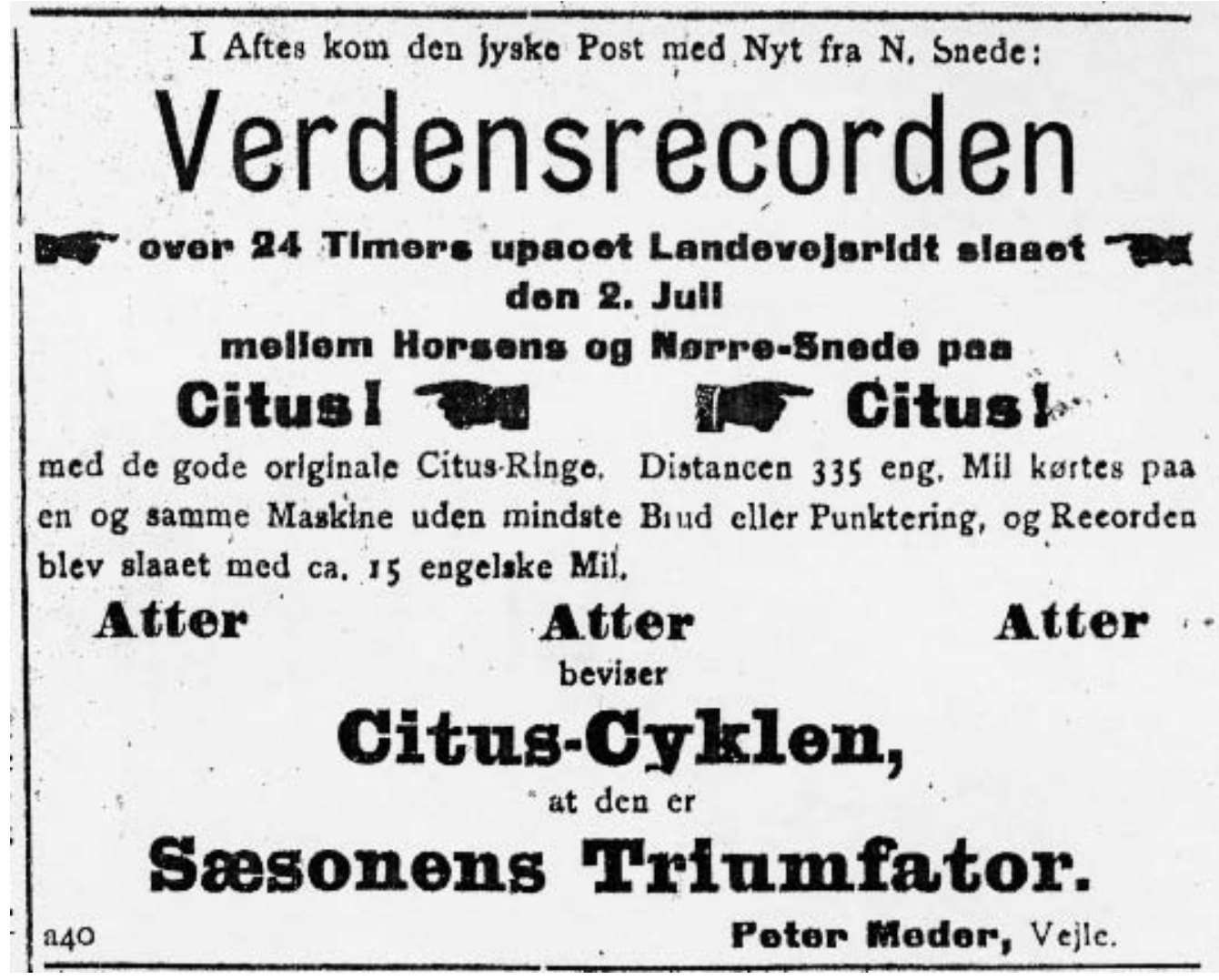

De kommercielle interesser skulle jo også passes, som det fremgår af denne annonce $i$ Vejle Amts Folkeblad den 4. juli 1899. Rasmus Jorgensen havde brugt Citus-cyklen til sine rekorder.

det sidste Stykke endog med 5 Mils Fart«. Den tidligere rekord lød på 53 timer og 40 minutter, men den havde Jørgensen trykket ned til 47 timer og 19 minutter.

I 1900 satte Rasmus Jørgensen igen en rekord, nemlig den danske rekord i kørsel over 12 timer. Den tidligere rekord lød på 52 danske mil, men på cykelbanen i Horsens lykkedes det Jørgensen at øge til 53 mil. $^{20}$

Sukkerkoger Gustav Heede var i begyndelsen af det 20. århundrede en af landets dominerende brydere og vægtløftere. Stor, stærk og smidig vandt han adskillige mesterskaber, og han var også meget tæet på at blive Europamester i 1905, da dommerne ved mesterskaberne i Berlin overså, at han havde modstanderen nede allerede tidligt $\mathrm{i}$ kampen. Dengang brødes man, indtil en af deltagerne havde begge skuldre i madrassen - ikke noget med point og på tid, som det fremgår af Gustav Heedes udtalelse til Vejle Social-Demolrat den 31. december 1943:

»Hein og jeg lurede lidt paa hinanden, saa gik jeg til Sagen med ungdommelig Iver for at faa en Afslutning, jeg skulde vare fardig og med Formiddagstoget hjem til Danmark. Hein var med sine 28 


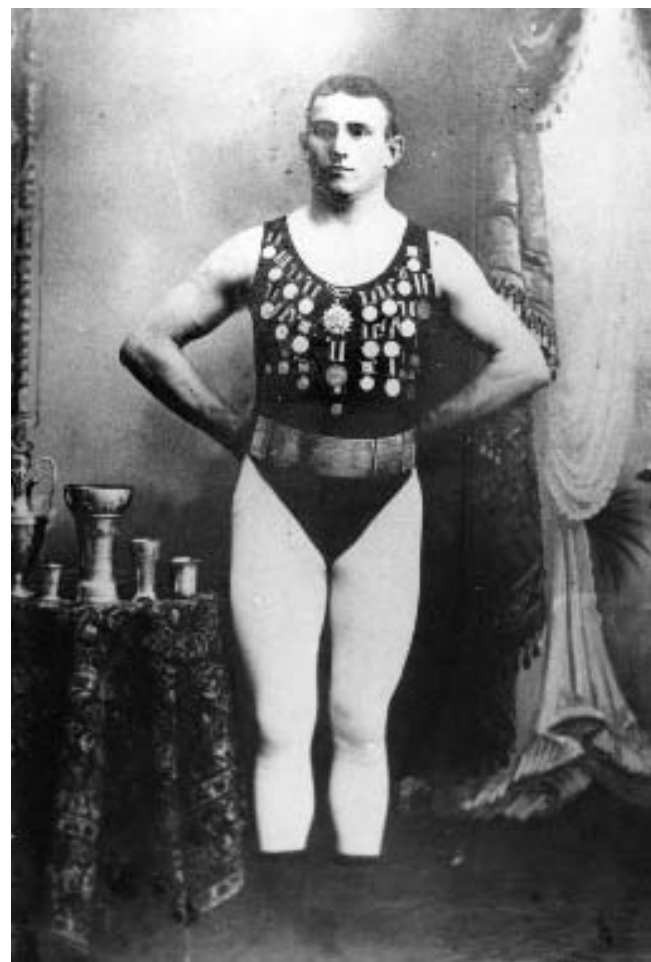

Bryderen Gustav Heede med stcerkt dekoreret bringe. (Vejle Byhistoriske Arkiv \& Stadsarkiv).

Aar mere dreven og erfaren end jeg, men det blev en god Kamp. Efter 10-12 Minutter havde jeg ham nede paa et Hovedfaldsgreb. Alle havde set det, men ikke Dommerne. Sikke en Larm og Staahej, der blev, men vi fortsatte ufortrodent. En 3-4 Gange havde Hein mig i et omvendt Livtag, men hver Gang kom jeg fri, men efter en god halv Times Brydning lykkedes Grebet for ham; pludselig sad jeg der, og, vupti, vars'artig, der laa jeg regulart med begge Skuldre mod Madrassen. Hein var Europamester, jeg Nr. $2 \ll$.

Gustav Heede, der var født 1884, begyndte at bryde i Vejle Atletklub i 1899, og 1905 var faktisk året, hvor han brød igennem. Over tre søndage måtte han rejse til $\mathrm{K} \varnothing$ benhavn for at kæmpe om det danske mesterskab, og da det var i hus med en sejr over Sofus Jensen, skulle Gustav søndagen efter til europamesterskaberne i Berlin. Et hårdt program for den unge mand, der dog fortsatte $i$ årene derefter som en af atletsportens store.

Gustav Heede blev en overgang erklæret for professionel, fordi han havde modtaget penge for at bryde mod cirkusdirektør Bech-Olsen i dennes cirkus. For at styrke tilstrømningen til cirkusforestillingerne havde mesterbryderen Bech-Olsen, der vejede 290 pund, udlovet $200 \mathrm{kr}$. til den, der kunne gå tyve minutter imod ham. Gustav Heede, der var 100 pund lettere end cirkusdirektøren, vandt de $200 \mathrm{kr}$. og flere til, for de følgende aftener gentog de to brydere kampen. På grund af disse kampe blev Heede frataget sine amatørrettigheder i en periode.

Gustav Heede var udlært sukkerkoger, og oprettede i 1921 sin egen bolsjefabrik, der endnu eksisterer. ${ }^{21}$

\section{Sportens gennembrud $i$ Vejle}

I det foregående er det fors $\emptyset$ gt at vise den vejlensiske udgave af sportens gennembrud. Der skal gøres opmærksom på, at der kun er tale om en skitse, for Vejles sportsog idrætsliv er desværre ikke undersøgt så grundigt endnu, som det er tilfældet $i$ andre provinsbyer. Men alle tegnene er der, for at man kan tale om sport: De mange klubog foreningsdannelser, organiseringen, rekordforbedringerne, konkurrencer mod udefra kommende modstandere osv. I det følgende skal nogle af hovedpunkterne trækkes op.

Gennemgangen af Vejle Amts Avis for 1899 viste, at der var en række foreninger i 
gang inden for sportens område. Gymnasterne lavede ikke blot $\varnothing v e l s e r$ for at opnå større smidighed og kraft, men også for at kunne vinde konkurrencer mod andre foreningers hold. Ligeledes konkurrerede man livligt inden for atletsporten. Der blev også gjort fors $\emptyset \mathrm{g}$ med fodbold, i første omgang uden større held, mens det gik bedre med kricket, fordi man havde været så heldig at lære en ellers ukendt teknik fra selve sportens moderland, England. Der var tilsyneladende gang i cykelsporten, men det er der for så vidt ikke noget overraskende i, eftersom netop cykling var en af de største grene i sportens gennembrud. Idrætsforskeren Jørn Hansen har peget på, at netop cykelsporten var væsentlig i den sportslige udvikling med ca. 100.000 aktive i $1899 !^{22}$

Vejles ældste klub, Sejlklubben Neptun, er lidt speciel i denne sammenhæng, fordi man på den ene side konkurrerede på livet løs på fjorden, men samtidig havde sportsudfoldelserne også karakter af friluftsliv og adspredelse. En anden sportsgren, der fortrinsvis appellerede til byens bedre kredse, nemlig tennis, viste også en blanding af det sportslige og det sociale. De vejlensiske tennisspillere opnåede ikke de store resultater, men det var behagelig træning, og der blev ifølge forhandlingsprotokollen afholdt nogle rigtig gode klubfester.

Ved en gennemlæsning af tidens aviser får en klar fornemmelse af medierne i høj grad var med til at understøtte det sportslige gennembrud. Ikke blot var der ofte referater fra sportskampene, der blev også brugt en del spalteplads på resultatlister. Man har indtrykket af, at netop de opnåede resultater var meget vigtige for læserkredsen, både med hensyn til at se, hvem der nu havde vundet en bestemt konkurrence, men også tider, længder, højder osv.

Det sportslige gennembrud er også karakteriseret ved en opprioritering af sports- anlæg, og her skete der også nogle forbedringer i Vejle. Sportspladsen ved Horsensvej blev styrket, der blev bygget klubhuse, tennisklubben fik bedre baner osv. Men den store milepæl på anlægsområdet kom først i begyndelsen af 1920'erne, hvor de ovenfor nævnte klubber, minus sejlklubben, men plus KFUM's idrætsafdeling, stiftede Samvirkende Idrætsklubber i Vejle (SIV) den 25. januar 1921. Denne sammenslutnings fornemste mål var at få bygget et stort, tidssvarende idrætsanlæg. Allerede i november 1921 kom arbejdet med stadion i Nørreskoven i gang som beskæftigelsesarbejde, og den 1. juni 1924 blev den nye idrætspark indviet. Tennisklubben havde da allerede været i gang på anlægget næsten et år. ${ }^{23}$

Vejle opnåede som nævnt også at få et par sportsmænd omkring århundredskiftet, der var talentfulde nok til at stikke hovedet op over den almindelige mængde af sportsfolk. Cykelrytteren Rasmus Jørgensen ved vi ikke meget om, men hans rekorder i 1899 og 1900 var ganske spektakulære. Han var et meget tydeligt eksempel på den moderne tids sportsmand, der ønskede at sætte rekorder. Bryderen og vægtløfteren Gustav Heede var også et rigtigt konkurrencemenneske. I den klassiske brydedisciplin, hvor man fortsatte kampen, indtil en af modstanderne var slået ved at have begge skuldre i madrassen, klarede Heede sig fint, og han blev endda også pengebryder, skønt hans kampe mod Bech Olsen nærmest var show. Sporten var imidlertid så godt organiseret, at han derefter i en periode blev udelukket, fordi et af idealerne, der endnu hyldedes, var amatør-idrætsmanden. Men at Gustav Heede også hørte en ældre tid til, afslørede han i interviewet i Socialdemokraten i 1943, hvor han til slut blev spurgt, hvordan han så på brydningen i dag: 
»Det er ikke det samme som f $\phi r$, der er for megen Passivitet $i$ Brydekampene nu. Det med, at der brydes paa Tid og med Points g $\phi r$ Bryderne saa forsigtige og frygtsomme, og naar de endelig har faaet et godt Greb og nogle Points, gaar de og passer paa ikke atter at miste Forspringet. Noh, lad dem brydes, til en af dem ligger der, saa skal de nok gaa til Sagen ${ }^{24}$

\section{Noter}

1. F.eks. citerer Johnny Wøllekær i sit værk om Odenses idrætsliv Fyens Stiftstidende for at udnævne Odense til nr. et blandt danske provinsbyer, når det drejede sig om sport, især gymnastik, cykling og boldspil i 1900. Johnny Wøllekær, 2001, s. 50.

2. Johnny Wøllekær, 1997.

3. Vejle Amts Avis, 4/9 1899.

4. Ibid., 4/12 og 5/12 1899.

5. Ibid., 8/9 1899.

6. Ibid., 27/1, 4/12, 12/12 1899.

7. Ibid., 20/3 1899.

8. Ibid., 11/11 1899.

9. Ibid., 5/6 1899.

10. Ibid., 15/5, 12/6 1899.

11. Ibid., $11 / 7$ og 17/7 1899 .

12. Claus Nielsen, 1990 s. 65; Jørn Hansen, 1990, s. 81-83, Johnny Wøllekær, 1999, s. 31-33; Else Trangbæk, 1995, Vejles Historie, bind 3, 1996, s. 178-180.

13. Vejle Boldklub 1891 - 3. maj-1941; Vejles Historie, bind 2, s. 181-182, Torben Jacobsen, 1986.

\section{Litteratur}

Jørn Hansen, »Kropsudfoldelse - fra sport til jogging. Det moderne - det traditionsforankrede - det postmoderne«. I: Den jyske Historiker, nr. 53 (Århus, 1990).

Asbjørn Hellum og Arne Rahbek, Gymnastik i 100 år. Vejle Gymnastik-Forening (1988).

Torben Jacobsen, »De første idrætskvinder i Vejle før 2. verdenskrig«. I: Idratshistorisk Årbog 1986, (1986).

Claus Nielsen, »Øiet aabnes, Legemet udvikles og Hurtigheden skærpes « - sportens fremkomst og gennembrud i Århus«. I: Den jyske Historiker, nr. 53 (Århus, 1990).

Poul Porskær Poulsen, »Fra sandbakkerne til idrætsparken. Vejle Lawn Tennis Klubs første år«. I: Vejlebogen 2000 (2000), s. 53-55.

14. Sejlklubben Neptuns arkiv, A 2293 (51), Vejle Byhistoriske Arkiv \& Stadsarkiv (VBA).

15. Asbjørn Hellum og Arne Rahbek, 1988.

16. VAK gennem 75 år, 28. november 1897 - 28. november 1972.

17. Vejle Tennis Klubs arkiv, A 2333, VBA; Poul Porskær Poulsen, 2000, s. 53-55.

18. Vejle Roklub 1901-2001; Vejle Roklubs arkiv, A 2085, VBA.

19. Vejle Idræts Forenings arkiv, A 2298 (8) (19), VBA.

20. Vejle Amts Avis, 11/6, 14/8, 22/8, 21/9, 25/9 1899; Vejles Historie, bind 2, s. 185. Desuden oplysninger fra Odense Stadsarkiv.

21. Vejle Social-Demokrat, 31/12 1943, Vejle Amts Folkeblad, 10/5 1954.

22. Jørn Hansen, 1990, s. 84.

23. Vejles Historie, bind 2, s. 182-183.

24. Vejle Social-Demokrat, 31/12 1943.

Else Trangbæk (red.), Dansk Idratsliv, bind 1 (Кøbenhavn,1995).

Vejle Boldklub 1891 - 3. maj- 1941.

Vejles Historie, bind 3, Vejles industri 1732-1996 (1996).

Vejles Historie, bind 2.

Johnny Wøllekær, »Mellem sport, adspredelse og selskabelighed - træk af odenseansk cykelsport ved århundredskiftet«. I: Idratshistorisk Årbog 1997 (Odense, 1997).

Johnny Wøllekær, »Hvad man nu kalder Sport« - en empirisk undersøgelse af sportens gennembrud $i$ Odense«. I: Idratshistorisk Årbog 1999 (Odense, 1997).

Johnny Wøllekær, Odense $i$ bevagelse - strejftog $i$ byens idratshistorie (Odense, 2001). 